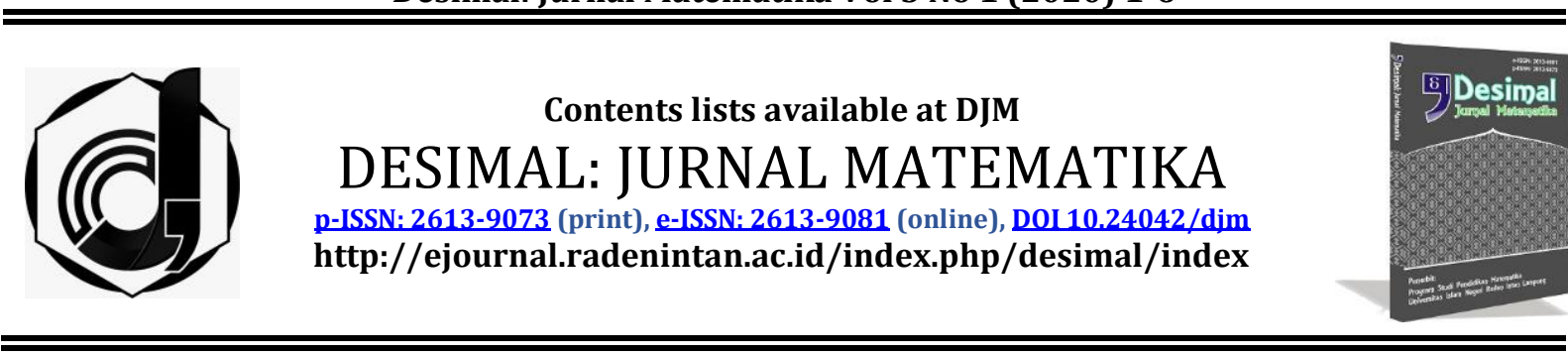

\title{
How Mathematical Reasoning Abilities can be improved? : A Study Case at Islamic Boarding School
}

\author{
Syamsul Huda ${ }^{1}{ }^{*}$, Haya Nadirah Kharisma ${ }^{2}$, Isti Qoma ${ }^{2}$, Kittisak Jermsittiparsert ${ }^{3}$ \\ ${ }^{1}$ Institut Agama Islam Negeri Kediri, Indonesia \\ 2 Universitas Islam Negeri Raden Intan Lampung, Indonesia \\ ${ }^{3}$ Chulalongkorn University, Bangkok, Thailand
}

\section{ARTICLE INFO}

\section{Article History}

Received : 19-08-2019

Revised : 22-11-2019

Accepted : 10-01-2020

Published :26-01-2020

Keywords:

Learning Cycle;

Problem Based Learning;

Matematical Reasoning Ability.

*Correspondence: E-mail:

syamsulhuda@iainkediri.ac.id

Doi:

$\underline{\text { 10.24042/djm.v3i1.5320 }}$

\begin{abstract}
The development of mathematical reasoning ability of students affect the process of settlement of problems exiting in the process of learning mathematics. This study has the objective to determine the learning model that is effective between the Problem Based Learning models and the Learning Cycle 5E models. This study using quantitative study, data analysis techniques using T-test. The study results obtained it can be concluded that, mathematical reasoning ability of students has increased more effectively when the learning process apply the Problem Based Learning models.
\end{abstract}

\section{INTRODUCTION}

Mathematics learning has always been a problem in itself for students at various levels. Reasoning for existing material is one of the various causes of the problem. Especially when students are faced with questions that require a high ability to reason to be able to determine the completion that must be taken. The introduction of reasoning ability to students as early as possible, will enable students to feel helped to understand the learning that is taking place and allow students to increase their confidence while reducing the level of fear of students in solving existing problems (Pitriati, 2019). Based on previous research, research has been conducted that discusses students' reasoning abilities, by pairing them with several learning models such as the Student Question Have model, Advance Organizer, Numbered Heads Together (Burais, Ikhsan, \& Duskri, 2016; Sulianto, Sunardi, Anitah, \& Gunarhadi, 2019; Yenni \& Aji, 2016). Judging from 
previous studies students' mathematical reasoning ability becomes an interesting topic to be reviewed.

The 5E learning cycle model is one of the many learning models that creates opportunities for students to actively participate in the learning process. Where it can improve students' mathematical reasoning abilities. Stages in the Learning Cycle model, students are guided to be able to find and discover new knowledge by themselves (Asmawati \& Wuryanto, 2014). Based on previous research there are studies that use the Learning Cycle 5E learning model to affect the ability to understand mathematical concepts, to learning outcomes, to the ability to solve mathematical problems (Asmawati \& Wuryanto, 2014; Pratiwi, 2016; Sulastri, Mariani, \& Mashuri, 2015).

There are several learning models besides the $5 \mathrm{E}$ learning cycle model that might be used to improve students' reasoning abilities, one of them is the Problem Based Learning (PBL) learning model. The learning process in the learning model Problem Based Learning students are made face to face with a problem so as to develop the ability to reason students and students can by skillfully complete (Lestari \& Yudhanegara, 2015). Based on previous research, research has been carried out using the Problem Based Learning learning model affecting problem solving, students' critical thinking abilities, and student learning outcomes (Gunantara, Suarjana, \& nanci Ristini, 2014; Nurkhasanah, Wahyudi, \& Indarini, 2011; Situmorang \& Samosir, 2018).

Previous research also conducted research using the Learning Cycle and Problem Based Learning models of students' reasoning abilities (Permana \& Sumarmo, 2007; Pitriati, 2019). In terms of previous research, no one has explained the learning model which is more effective if it is used to develop students' reasoning ability between the two learning models (Kasayanond, Umam, \& Jermsittiparsert, 2019). So the purpose of this article is to look at the learning model between the Learning Cycle 5E learning model and the Problem Based Learning learning model which is more effective if used to develop students' mathematical reasoning abilities.

\section{METHOD}

This research is a quantitative study, using the learning cycle learning model $5 \mathrm{E}$ and the problem based learning (PBL) learning model. Following the flow of research methods carried out.

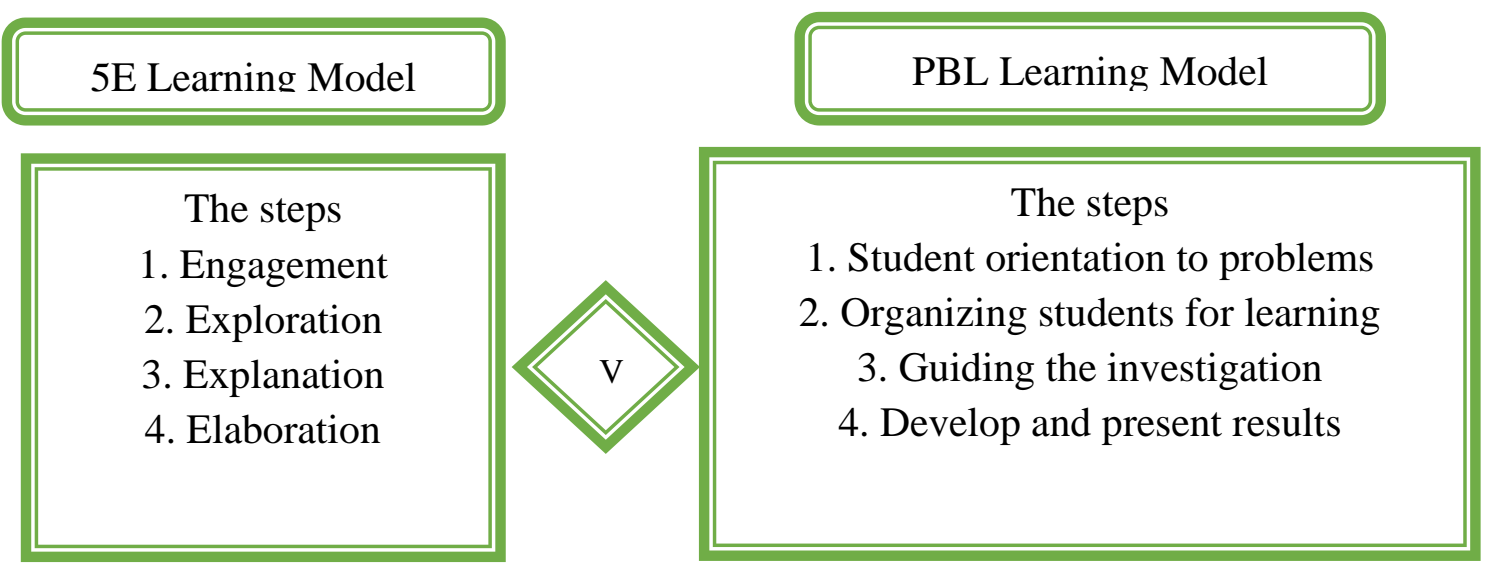

Figure 1. Research Design

Based on Figure 1. The study applied learning by using two learning models namely the 5E model and the PBL model. The steps of the $5 \mathrm{E}$ learning model include 
Desimal, 3 (1), 2020 - 3

Syamsul Huda, Haya Nadirah Kharisma, Isti Qoma, Kittisak Jermsittiparsert

engagement, exploration, explanation, elaboration, and evaluation. The steps of the PBL learning model include student orientation to the problem, organizing students to learn, guiding individual and group investigations, developing and producing work, and analyzing and evaluating. Data collection in this study used a pretest and posttest test. This research was conducted to see learning models between $5 \mathrm{E}$ learning models and PBL learning models that are more effective in improving mathematical reasoning abilities. The data analysis technique used is the T Test.

\section{RESULTS AND DISCUSSION}

Based on the results of research that discusses the improvement of students' mathematical reasoning abilities obtained from the pretest and posttest of the experimental class applying the Problem Based Learning learning model and the experimental class applying the $5 \mathrm{E}$ Learning Cycle learning model in order to obtain the following research results.

Table 1. descriptive data between the 5E learning cycle model and the Problem Based Learning (PBL) model

\begin{tabular}{|c|c|c|c|c|c|c|}
\hline & Mean & median & Varians & $\begin{array}{c}\text { Std. } \\
\text { varians }\end{array}$ & Min & Max \\
\hline $\begin{array}{c}\text { Model } \\
5 E\end{array}$ & 57,77 & 54,50 & 481,261 & 21.938 & 13 & 100 \\
\hline $\begin{array}{c}\text { Model } \\
\text { PBL }\end{array}$ & 68,77 & 66,67 & 191,897 & 13,835 & 43 & 100 \\
\hline
\end{tabular}

Based on Table 1, descriptive data between the $5 \mathrm{E}$ learning cycle learning model and the Problem Based Learning (PBL) learning model shows that the average value of the Problem Based Learning (PBL) model is better than the $5 \mathrm{E}$ learning cycle model. Also seen the minimum value in the Problem Based
Learning PBL model is also better than the $5 \mathrm{E}$ learning cycle model. This results in that the PBL Problem Based Learning model is better than the $5 \mathrm{E}$ learning cycle model in improving mathematical reasoning ability. Furthermore, it will be seen more clearly in Table 2, namely the independent sample test table.

Table 2. Independent sample test

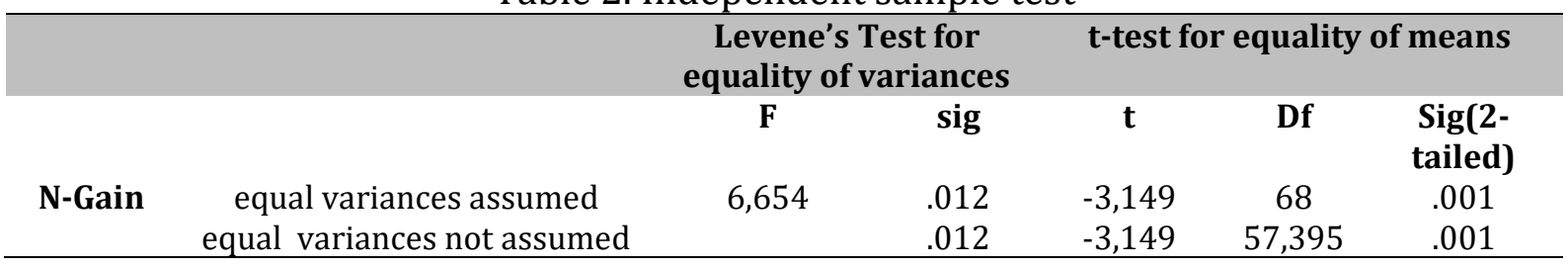

Based on Table 2 the independent sample test can be seen that:

Hypothesis testing

$\mathrm{H}_{0}: \mu_{1} \geq \mu_{2}$

$\mathrm{H}_{1}: \mu_{1}<\mu_{2}$

$\mu_{1}=$ Average learning model learning cycle $5 \mathrm{E}$

$\mu_{2}=$ Average Problem Based Learning (PBL) learning model

Based on Table 2 it appears that the $\mathrm{P}$-value $<0,05$, so $\mathrm{H}_{0}$ the hypothesis test was rejected. This means that it can be concluded that the Problem Based Learning (PBL) learning model is more effective in improving mathematical reasoning ability than the $5 \mathrm{E}$ learning cycle learning model.

Learning model Learning Cycle 5E becomes one of the learning models with constructivist approaches. This opinion was seen in the process of applying the Learning Cycle 5E learning model that 
contained five stages. The five stages are engagement, exploration, explanation, elaboration, and evaluation (Asmawati \& Wuryanto, 2014). Stages of engagement is a process of brief introduction to students about the material that will be discussed in the learning process. Exploration is the process by which students are given the opportunity to test, do and record what they observe related to the subject matter. Explanation is the process by which students are given the opportunity to present the results of an experiment using their own language. Elaboration is a time when students apply the concepts they have acquired in other situations. Finally, the evaluation stage where students will be asked their understanding of the material discussed in the learning process (Pratiwi, 2016).

The advantage of implementing the 5E Learning Cycle learning model in the learning process according to Soebagio is that this learning model is student centered, new information given to students will be linked to knowledge that has been obtained before (Munifah, Huda, et al., 2019), the learning process is oriented towards investigation and new discoveries to solve problems, use real experience makes the learning process more meaningful, makes students do not rely on traditional ways of learning that are more memorizing, students will become more active, critical and creative (Asmawati \& Wuryanto, 2014).

Problem Based Learning learning model is a learning model that first provides a presentation of a problem that has been designed, where the context is relevant to the material to be discussed in the learning process. The process will give students knowledge and understanding of concepts, be able to think more critically, be able to build independence in learning, increase collaboration in group work processes, and problem solving will be further increased (Permana \& Sumarmo, 2007).
The steps taken in the learning process that apply the Problem Based Learning learning model begins with the teacher directing students to be oriented to the existing problems. The second step is the teacher forms groups for students to learn in stages with the existing problems. The third step the teacher guides the discussion process that is in the group. The fourth step students are asked to develop the results obtained from group discussions and present them. The final step where the teacher and students do an analysis of the results presented and evaluate the results obtained (Sulastri et al., 2015).

Based on the explanation, it can be seen that the Problem Based Learning model is more effective in improving students' mathematical reasoning abilities compared to the Learning Cycle 5E learning model. This can be seen from the different stages that are applied to each learning model (Munifah, Romadhona, et al., 2019). The difference can be seen from the steps in the Problem Based Learning model applying independent learning students but the teacher still contributes to guide in each process such as the teacher divides the discussion group but still guides directly. Contrary to the learning process that is applied in the Learning Cycle 5E learning model that emphasizes students processing independently and the teacher does not directly guide it.

Seeing the results of previous studies, that the Problem Based Learning model of learning can affect the ability of critical thinking, problem solving, and student learning outcomes (Gunantara et al., 2014; Nurkhasanah et al., 2011; Situmorang \& Samosir, 2018). Learning Cycle 5E learning model on the results of previous research can also affect the ability to understand mathematical concepts, mathematical problem solving abilities and student learning outcomes (Asmawati \& Wuryanto, 2014; Pratiwi, 
Desimal, 3 (1), 2020 - 5

Syamsul Huda, Haya Nadirah Kharisma, Isti Qoma, Kittisak Jermsittiparsert

2016; Sulastri et al., 2015). Both of these learning models when used to find out which model is more effective to improve students' mathematical reasoning abilities will be more effective if the Problem Based Learning learning model is applied in the learning process (Munifah, Tsani, et al., 2019).

\section{CONCLUSIONS AND SUGGESTIONS}

Based on the research, there is a difference between the application of the Problem Based Learning learning model and the Learning Cycle 5E learning model. It was concluded that the Problem Based Learning model gave a more effective impact on improving students' mathematical reasoning abilities compared to the Learning Cycle $5 \mathrm{E}$ learning model.

Suggestions for future research might be possible to do research with other learning models that might have a more effective impact on improving students' mathematical reasoning abilities. This will help in solving some of the problems that are often faced by students when the mathematics learning process is ongoing.

\section{REFERENCES}

Asmawati, R., \& Wuryanto. (2014). Keefektifan Model Pembelajaran LC 5E Dan TSTS Berbantuan LKPD Terhadap Hasil Belajar. Jurnal Kreano, 5(1), 26-32.

Burais, L., Ikhsan, M., \& Duskri, M. (2016). Peningkatan Kemampuan Penalaran Matematis Siswa melalui Model Discovery Learning. Jurnal Didaktik Matematika, 3(1), 77-86. https://doi.org/10.24815/jdm.v3i1. 4639

Gunantara, G., Suarjana, M., \& nanci Ristini, P. (2014). Penerapan Model Pembelajaran Problem Based Learning Untuk Meningkatkan Kemampuan Pemecahan Masalah Matematika Siswa Kelas V. Mimbar, 2(1), 8-20.
Kasayanond, A., Umam, R., \& Jermsittiparsert, K. (2019). Environmental Sustainability and its Growth in Malaysia by Elaborating the Green Economy and Environmental Efficiency. International Journal of Energy Economics and Policy, 9(5), 465-473. https://doi.org/https://doi.org/10.3 2479/ijeep.8310

Lestari, K. E., \& Yudhanegara, M. R. (2015). Penelitian Pendidikan Matematika.

Munifah, M., Huda, S., Hamida, U. D., Subandi, Syazali, M., \& Umam, R. (2019). The Use of Management Strategies to Attract the Public ' $s$ Interest in Pesantren: A New Model for Pesantren Dynamics Study. International Journal of Innovation, Creativity and Change, 8(8), 363-383. Munifah, M., Romadhona, A. N., Ridhona, I., Ramadhani, R., Umam, R., \& Tortop, H. S. (2019). How to Manage Numerical Abilities in Algebra Material? AlJabar : Jurnal Pendidikan Matematika, 10(2), 223-232. https://doi.org/10.1017/CB097811 07415324.004

Munifah, Tsani, I., Yasin, M., Tortop, H. S., Palupi, E. K., \& Umam, R. (2019). Management System of Education: Conceptual Similarity (Integration ) between Japanese Learning System and Islamic Learning System in Indonesia. Tadris Jurnal Keguruan Dan Ilmu Tarbiyah, 4(2), 159-170. https://doi.org/10.24042/tadris.v4i 2.4893

Nurkhasanah, D., Wahyudi, W., \& Indarini, E. (2011). Penerapan Model Problem Based Learning Untuk Meningkatkan Kemampuan Berpikir Kritis Siswa Kelas V Sd. Satya Widya, 35(1), 52-56. https://doi.org/10.24246/j.sw.2019. v35.i1.p33-41

Permana, Y., \& Sumarmo, U. (2007). Mengembangkan Kemampuan Penalaran dan Konekso Matematik Siswa SMA Melalui Pembelajaran 
Desimal, 3 (1), 2020 - 6

Syamsul Huda, Haya Nadirah Kharisma, Isti Qoma, Kittisak Jermsittiparsert

Berbasis Masalah. Educationist, I(2), 116-123.

Pitriati, P. (2019). Pembelajaran Matematika Menggunakan Model Learning Cycle 5E Untuk Meningkatkan Kemampuan Penalaran Matematis Siswa SMP 30 Padang. Indonesian Journal of Science and Mathematics Education, 2(2), 235-244.

https://doi.org/10.24042/ijsme.v2i2 .4397

Pratiwi, D. D. (2016). Pembelajaran Learning Cycle 5e berbantuan GeoGebra terhadap Kemampuan Pemahaman Konsep Matematis. AlJabar: Jurnal Pendidikan Matematika, 7(9), 191-202. https://doi.org/10.1017/CB097811 07415324.004

Situmorang, M. S., \& Samosir, K. (2018). Penerapan Model Pembelajaran Problem Based Learning (Pbl) Untuk Meningkatkan Hasil Belajar Siswa
Smp Negeri 1 Rantau Selatan. Inspiratif: Jurnal Pendidikan Matematika, 3(1), 1-7. https://doi.org/10.24114/jpmi.v4i1. 10773

Sulastri, E., Mariani, S., \& Mashuri. (2015). Studi Perbedaan Keefektifan Pembelajaran LC-5E dan CIRC Terhadap Kemampuan Pemecahan Masalah Matematika. Kreano, 6(1), 26-32.

Sulianto, J., Sunardi, S., Anitah, S., \& Gunarhadi, G. (2019). Analisis Implementasi Pembelajaran di Sekolah Dasar pada Pengembangan Model Advance Organizer berbasis Pendekatan Open Ended untuk Meningkatkan Penalaran Siswa. 3(4), 396-403.

Yenni, \& Aji, R. S. (2016). Analisis Kemampuan Penalaran Matematis Siswa Smp Melalui Model Pembelajaran Numbered Heads Together. Jurnal Prima, V(II), 78-80. 